\title{
FACTORS FOR SUCCESS IN AN SAP CERTIFICATION ACADEMY
}

Frank Andera, Central Michigan University, ander1fj@cmich.edu

Katherine Soave, Central Michigan University, soave1kl@cmich.edu

\begin{abstract}
Enterprise systems, i.e. SAP, are prevalent in most corporations today, and fundamental enterprise systems knowledge and experience are vital for CMU graduates entering the workforce. CMU's SAP Certification Academy provides this knowledge and experience to students pursuing degrees through the College of Business Administration. This study examined the factors that had an impact on students, success in the SAP Certification Exam, administered at the end of the SAP Certification Academy. The study found that additional coursework (specifically in accounting information systems), a higher GPA, and group study sessions correlated with a higher score on the SAP Certification Exam. The results of the study also provided guidance to CMU as well as other SAP University Alliance programs in their examination of the factors that best prepare students for the SAP Certification Academy.
\end{abstract}

Keywords: SAP, ERP, University Alliance Programs, ERP education, SAP certification.

\section{INTRODUCTION}

Whereas Enterprise Systems (ES) once were an added component to give large business a competitive advantage, today these systems are an integral part of the majority of corporations. Rather than being a state-of-the-art information system application, enterprise systems are now considered basic "plumbing" for an organization [7]. "Enterprise system" is the new term to describe former "enterprise resource planning" systems, which had fewer capabilities and focused primarily on materials resource planning [4]. These systems allow businesses to integrate all of their processes (finance, logistics, human resources, etc.) and connect them through a single data store. In doing so, it provides a seamless flow of information which is updated in real time. SAP R/3 is one such example of an enterprise system that connects the core transaction processing activities of a business [6]. Not only does an enterprise system allow management to see a holistic view of their organization without accessing multiple systems, but it also allows each department to input information which is reflected throughout the organization [10].

Because of the prominence of enterprise systems in today's business world, both SAP America and universities across the country saw the need to close this skill gap in college graduates. In order for students and business to succeed, it was necessary to educate students on ES, and for this to happen, businesses needed to help support these training programs. SAP capitalized on this goal in 1996, when it established the SAP University Alliance Program (UAP). The program began with thirteen schools that were given SAP software and faculty training support [3]. From there, the program continued to grow across the nation and world. Today, there are hundreds of universities and technical institutes in the SAP University Alliance Program in over 30 countries [9], and each school's program continues to develop and evolve to create more opportunities for students and employers alike.

The UAP schools have taken different approaches to incorporate an SAP component into their coursework. At Central Michigan University (CMU), Information Systems majors were able to take in-depth courses using SAP R/3, while other business majors were able to take courses in their respective functional areas, including accounting and human resource management [3]. As of 2009, CMU has offered 22 unique SAP-supported courses throughout the life of its UAP in both undergraduate and graduate curriculums, including several online graduate classes. The classes spanned across several subject areas: accounting, business information systems, finance, management, and marketing. In addition, courses were available for the Master of Science in Information Systems as well as a Master of Business Administration. The curriculum at $\mathrm{CMU}$ also includes a Bachelor of Science in Business Administration (BSBA) core course required of all undergraduate College of Business Administration students. This course, BUS 301, titled "Integrated Business Experience" focuses eight weeks of instruction on SAP and other ES systems, along with a number of simulated exercises in the SAP R/3 
environment [5]. Another original member of the SAP UAP, California State University Chico, took a similar approach to incorporating the software into its curriculum. The university offers SAP-supported courses in accounting and finance, production management, and management information systems. As of 2000, California State University Chico had plans to add a number of classes from the marketing and management disciplines [2].

In addition to this coursework, SAP began a pilot project for the SAP $\mathrm{R} / 3$ Process Integration Certification Academy in 2000. The goals of the project were: "to provide an overview of processoriented management, for a business point of view, to gain knowledge of core business processes and the integration of acquired R/3 System skills through one's knowledge of basic business processes." [8]. The original SAP Academy held at CMU lasted four weeks and consisted of lectures, SAP exercises, a group case project, and finally the SAP certification exam; classes were limited to twenty five students [4]. Over the years, the format of the Academy has changed. Presently, the SAP Academy lasts ten days, and in recent years classes have had over thirty students. In addition to this, the day-to-day structure of the Academy was modified, eliminating the case project and focusing much more on lectures and exercises in preparation for the SAP certification exam. Table 1 includes the basic business processes currently covered in the SAP Academy. In addition to these processes, the SAP Academy discusses the basic structures (i.e. organization and master data) used throughout SAP, NetWeaver as a technology infrastructure, and NetWeaver Business Intelligence (BI) as a reporting and analysis tool [11].

\section{Table 1}

\begin{tabular}{|l|l|}
\hline $\begin{array}{l}\text { TERP10 - MySAP ERP - Integration of Business } \\
\text { Processes }\end{array}$ \\
\hline Financial Accounting & Managerial Accounting \\
\hline $\begin{array}{l}\text { Human Capital } \\
\text { Management }\end{array}$ & Procurement \\
\hline Inventory Management & Material Planning \\
\hline Manufacturing Execution & Plant Maintenance \\
\hline Customer Service & $\begin{array}{l}\text { Lifecycle Data } \\
\text { Management }\end{array}$ \\
\hline Sales Order Management & $\begin{array}{l}\text { Program Project } \\
\text { Management }\end{array}$ \\
\hline $\begin{array}{l}\text { Strategic Enterprise } \\
\text { Management }\end{array}$ & \\
\hline
\end{tabular}

Along with the structural changes of the Academy, its cost has also fluctuated as the SAP UAP works with Universities to determine an appropriate cost. Figure

Volume XI, No. 2, 2010
1 displays the cost changes of the Academy during the ten years it has been offered at CMU.

Figure 1

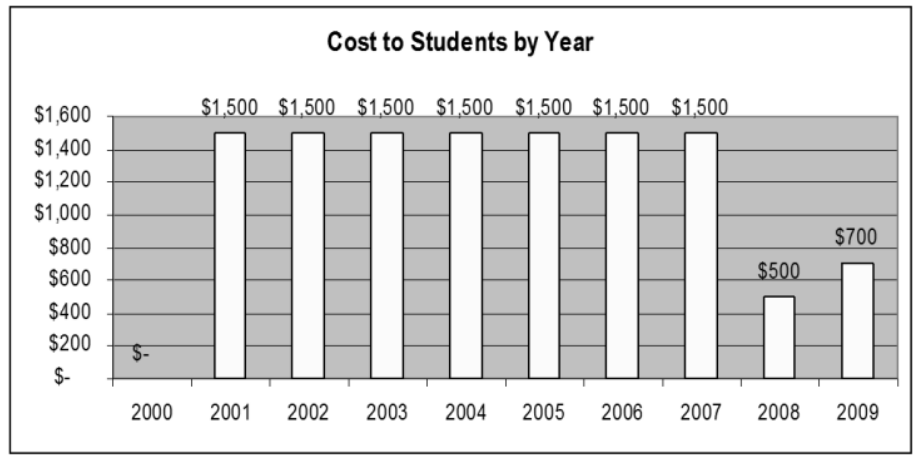

The number of participants in the Academy has also changed greatly over the past ten years. Figure 2 shows the number of participants enrolled in each year's SAP Academy.

Figure 2

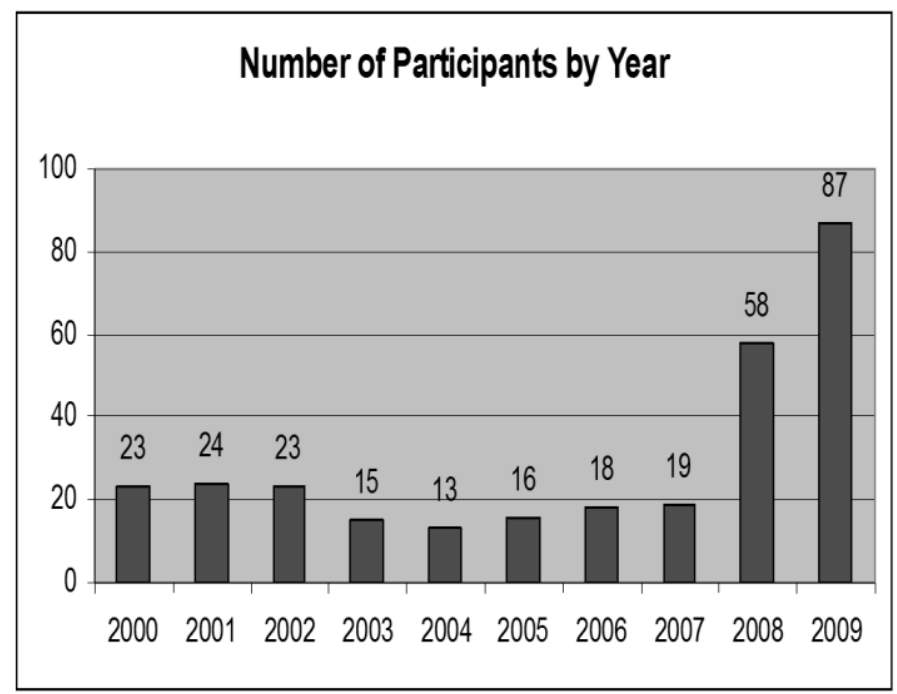

For the original SAP Academy at Central Michigan University, participants

were required to be juniors or seniors and must have taken at least two SAP-supported courses [4]. Over time, the prerequisites for the SAP Academy have changed through directives from SAP and through CMU's SAP University Alliance Program. Aside from SAP course requirements serving as a prerequisite to the SAP Academy, CMU does not require any additional prerequisites for the Academy such as GPA, class standing, etc. Because these other variables or prerequisites have never been studied, this research project will help the CMU College of Business Administration to adjust the possible prerequisites for enrollment in the Academy. In the past, research has been performed to analyze 
students' satisfaction with the SAP Academy. While the results from this research have shown that students are generally satisfied with the Academy, it is beneficial to consider the factors that relate to higher scores on the certification exam. If students enrolled in the Academy are better prepared, they will have a better chance for success and overall satisfaction with the Academy itself. Previous research has shown that graduates who have participated in courses supported by SAP and completed the SAP Academy generally have higher salaries than those who have not completed SAPsupported courses [1]. The purpose of this study was to analyze the factors that correlate with a higher or lower score on the TERP10 mySAP ERP Integration of Business Processes Certification Exam, with the results serving to adapt the current certification program to the changing needs of students enrolled in the College of Business Administration.

\section{METHODOLOGY}

Eighty-seven students participated in the 2009 SAP Academies held at Central Michigan University. The students were divided into two classrooms based on whether they were undergraduate or graduate students. Of the 87 , there were 49 graduate students and 38 undergraduate students. The survey was administered on the last day of instruction (Thursday) for the SAP Academy after the day's lesson was complete. The course instructors introduced the survey instrument, explained the purpose of the study, emailed students the electronic link to the online survey instrument, and passed around a basket of random numbers to the students in each room. In order to reduce response bias, the students were given random numbers which connected their survey responses and exam scores. The researchers also closed the survey instrument at 8 a.m. Friday morning to ensure that students had completed the survey prior to taking the SAP Certification Exam and receiving their scores.

Upon completion of the SAP Certification Exam on Friday morning, the teacher verified each student's score, collected the participant's random number, and recorded both on an anonymous score sheet which was returned to the researchers.

The survey was designed to collect basic demographic information on the students enrolled in the Academy. The demographic items differed slightly between undergraduate and graduate students, and are shown in Table 2.

Volume XI, No. 2, 2010
Table 2

\begin{tabular}{|l|l|}
\hline Undergraduate & Graduate \\
\hline Major & Program of Study \\
\hline Minor & $\begin{array}{l}\text { Received Undergrad. From } \\
\text { CMU (or other) }\end{array}$ \\
\hline Class Standing & \\
\hline Expected Graduation Date \\
\hline GPA \\
\hline Gender \\
\hline Age \\
\hline $\begin{array}{l}\text { Member of SAP University Alliance Student User } \\
\text { Group }\end{array}$ \\
\hline Member of other Registered Organization \\
\hline
\end{tabular}

In addition to this demographic data, the survey included questions that asked students which SAPsupported courses they had taken prior to the Academy, and how many hours they studied (both individually and with a partner/group). Next, the survey asked students to choose how strongly they agreed with a number of statements:

- I felt well-prepared for the SAP Academy.

- The SAP Academy will broaden my career opportunities.

- The SAP Academy was worth the cost.

- My instructor presented the SAP Academy material well.

- Academy participation is likely to increase my earnings in the near future.

These questions were included to assess a number of factors, from the perceived quality of Academy preparation, to reasons for participation, and satisfaction with course instructors. The final portion of the survey asked students to respond to three qualitative items:

- Why did you choose to participate in the SAP Academy?

- How will the SAP Academy specifically impact your career/professional development?

- Please provide any suggestions for improvement of the SAP Academy/SAP University Alliance Program.

Once again, the researchers wanted to identify some of the reasons that students chose to participate in the Academy. In addition, the last question allowed 
participants to provide practical feedback to the Director of the program. This item was not used in the analysis for this study.

Of the 87 SAP Academy participants, 51 students completed the survey, resulting in a response rate of $58.6 \%$. The results were analyzed using SPSS version 15.0 using simple linear regression and ANOVA. Using these surveys, along with the anonymous scores from the SAP exam, the researchers hoped to gain insight into the factors that correlated with a higher score on the SAP Certification Exam.

\section{FINDINGS}

Shown below in Table 3 are the basic descriptive statistics of the sample used in analysis for this study. Scores on the SAP Exam are out of 100 points with a score of 70 or above considered a passing score. Grade Point Average (GPA) at the researchers' university is on a 4-point scale.

\section{Descriptive Statistics}

Table 3

\begin{tabular}{|l|l|l|l|l|}
\hline & Minimum & Maximum & Mean & Std. Deviation \\
\hline Score & 63 & 89 & 75.44 & 6.81 \\
GPA & 2.48 & 4.00 & 3.38 & .49 \\
Age & 20 & 47 & 24 & 5.13 \\
\hline
\end{tabular}

The pass rate for the sample was $80 \%$, while the overall pass rate publicized by SAP America is $75 \%$. The sample consisted of $66 \%$ male and $34 \%$ female respondents. Students in the sample had a wide range of majors within the College of Business Administration both at the Undergraduate and Graduate levels. The following majors and programs of study were represented: Management Information Systems (MIS), Accounting, Accounting Information Systems (AIS), Management, Marketing, Logistics, Information Technology, Finance, Master of Science in Information Systems (MSIS), Master of Business Administration (MBA), Industrial Management \& Technology, and Economics.

Many of the variables tested in the regression analysis proved to be insignificant, however, at a 90\% confidence level, a few variables were statistically significant. Shown below in Table 4 are the results of the simple linear regression analysis performed in SPSS. The most significant variable was the student's GPA, which had a positive effect of about six points for each GPA point. The variables labeled "ACC 370" and "StudiedInGroup" were dummy variables, the first referring to the Accounting Information Systems and Controls course offered at the researchers' university, the second referring to whether students had spent any time during the Academy studying in a group. Both of these variables had a positive impact on the regression equation, roughly five points and three and a half points, respectively. The last significant variable included in the equation was "CountClass," which is the number of SAP-related courses the student had taken. Each additional SAP-supported course had a positive impact on the student's score by about one point.

\section{Coefficients(a)}

Table 4

\begin{tabular}{|c|l|l|l|l|l|}
\hline Model & \multicolumn{2}{|l|}{$\begin{array}{l}\text { Unstandardized } \\
\text { Coefficients }\end{array}$} & $\begin{array}{l}\text { Standardized } \\
\text { Coefficients }\end{array}$ & $\mathrm{t}$ & Sig. \\
\hline & $\mathrm{B}$ & $\begin{array}{l}\text { Std. } \\
\text { Error }\end{array}$ & Beta & $\mathrm{B}$ & $\begin{array}{l}\text { Std. } \\
\text { Error }\end{array}$ \\
\hline $1 \quad$ (Constant) & 48.411 & 5.202 & & 9.307 & .000 \\
GPA & 6.236 & 1.557 & .441 & 4.004 & .000 \\
ACC370 & 4.974 & 2.265 & .248 & 2.196 & .033 \\
$\begin{array}{l}\text { Studiedin } \\
\text { Group }\end{array}$ & 3.574 & 1.556 & .237 & 2.298 & .026 \\
$\begin{array}{l}\text { Count } \\
\text { Class }\end{array}$ & 1.250 & .729 & .197 & 1.714 & .093 \\
\hline
\end{tabular}

a Dependent Variable: Score

Displayed in Table 5 and Table 6 are the remaining outputs from SPSS for this simple linear regression analysis. The R Square score of .502 indicates that this can be used to describe the variance in about $50 \%$ of the data. Although this is not a particularly high R Square score, it was the highest of all of the models tested and is believed to be acceptable by the researchers considering the overall variability of the data set. Table 3 shows the overall significance of the regression model. With an $\mathrm{F}$ score of 11.844 , it appears that the regression is significant with $90 \%$ confidence. 


\section{Model Summary}

Table 5

\begin{tabular}{l|l|l|l|l|}
\hline Model & $\mathrm{R}$ & $\begin{array}{l}\mathrm{R} \\
\text { Square }\end{array}$ & $\begin{array}{l}\text { Adjusted } \\
\text { Square }\end{array}$ & $\begin{array}{l}\text { Std. Error of } \\
\text { the Estimate }\end{array}$ \\
\hline 1 & $.709(\mathrm{a})$ & .502 & .460 & 5.08030 \\
\hline a Predictors: (Constant), & CountClass, \\
StudiedinGroup, GPA, ACC370 \\
ANOVA(b)
\end{tabular}

Table 6

\begin{tabular}{|c|l|l|l|l|l|l|}
\hline \multicolumn{2}{|l|}{ Model } & $\begin{array}{l}\text { Sum of } \\
\text { Squares }\end{array}$ & df & $\begin{array}{l}\text { Mean } \\
\text { Square }\end{array}$ & F & Sig. \\
\hline 1 & Regression & 1222.724 & 4 & 305.681 & 11.844 & $\begin{array}{l}.000 \\
\text { (a) }\end{array}$ \\
& Residual & 1213.045 & 47 & 25.809 & & \\
\multicolumn{1}{|l|}{ Total } & 2435.769 & 51 & & & \\
\hline
\end{tabular}

a Predictors: (Constant), CountClass, StudiedinGroup, GPA, ACC370

b Dependent Variable: Score

The researchers believe this analysis to be reasonable. Students with a higher GPA more than likely have good study habits and work ethic, making it easier to comprehend information presented in the extensive lectures of the SAP Academy. Next, the Financial and Managerial Accounting modules have already been introduced to students that have participated in the ACC 370 course. One of the instructors for the 2009 Academy remarked that the accounting modules are a heavily tested segment, and perhaps one of the most difficult to understand. Students who have already been introduced to the material appear to have an advantage over those who have not. Participants who study in a group may also perform better on the exam due to the complex nature of some of the SAP Academy materials. By working in a group, students may have a better chance of making connections between different pieces of information and synthesizing their knowledge. Lastly, the number of SAP-related courses has a positive effect on the regression model. This is logical, since participants with more exposure to SAP will have more of a foundation to base their Academy studies on.

Several of the variables deemed statistically insignificant were surprising. For example, it may seem likely that students who studied for more hours would perform better on the certification exam.
Explanations for this variable's insignificance may be that there was not consistency in answers (i.e. some students may have considered time spent in class as time studying while others did not) as well as the quality of time spent studying. It was also expected that students in the MIS and MSIS programs would achieve higher scores on the certification exam since they are exposed to more in-depth SAP material throughout their college curriculums. This can be explained, among other reasoning, due to the fact that the SAP Academy focuses on a much more holistic approach to business processes, rather than some of the more detail-oriented topics discussed in MIS/MSIS coursework.

In addition to this regression analysis, the researchers analyzed some additional aspects of the data. Students with high scores on the Certification Exam (above 80 points) were separated from the sample, and were tested for a difference in mean $(\alpha=.1)$ in both GPA and number of SAP-supported courses taken. The mean GPA for students with high exam scores was 3.82 , which was statistically higher than the sample mean of 3.38. For high score students, the mean number of SAP-supported courses was 2.87, statistically higher than the sample mean of 1.83 . Although the regression analysis only indicated a one-point positive impact on students' exam scores for each SAP-related course, it is important to note that this significant difference between highachieving students and the sample population exists. In terms of prerequisites for the SAP Certification Academy, it may be valuable to require one additional SAP-related course.

\section{CONCLUSIONS AND FUTURE RESEARCH}

Currently, students wishing to participate in the SAP Certification Academy at CMU are only required to have completed SAP-related coursework. The results of this study show that the following variables correlate with a higher score on the TERP10 Certification exam: GPA, having taken the Accounting Information Systems course, having studied with a group during the Academy, and taking more SAP-supported courses. In order to create the ideal environment for students' success in the SAP Academy, it may be beneficial to adjust the current requirements for participation in the exam. For example, the CMU SAP University Alliance Program may choose to include a minimum grade point average for students wishing to participate. Another proposal could require students to take additional SAP-supported courses. In addition to this, the curriculum of the current introductory SAP course 
could be modified to provide more material that is currently presented in the Accounting Information Systems course (since only accounting majors may participate in the ACC 370S course). By ensuring that students are more adequately prepared to participate in the Academy, it will help a greater percentage of students succeed.

Up to this point in time, much of the research done on the SAP University Alliance program and the SAP Academy has been from an internal standpoint. It would be very beneficial to consider the success of students who have completed the SAP Academy, from both the students' perspectives and that of their employers. For instance, do employers really recognize a greater understanding of SAP in those who have completed the Academy? Are employers aware of the University Alliance Program and how it adds both a breadth and depth of knowledge in SAP? If schools can examine employers' knowledge of the SAP University Alliance program, they will be able to better connect with these employers in order to provide better opportunities for students seeking internships and post-graduation employment. In addition, research involving SAP employers may also provide insight into skill gaps and areas that should be strengthened in the college curriculum. The University Alliance Program should continue to monitor students' success in the SAP Academy to determine whether students are sufficiently prepared to participate in the Academy and take the SAP Certification Exam. By considering students' GPA, coursework, and study methods, the CMU SAP University Alliance Program has gained further insight into the factors for student success in the SAP Certification Academy.

\section{REFERENCES}

[1] Andera, F., Dittmer, A., and K. Soave. "Salary Comparison Study of SAP vs. Non-SAP Business Graduates." Issues in Information Systems. 9:2, 2008, pp. 607-613.

Becerra-Fernandez, I., K. E. Murphy, and S. J. Simon. "Integrating ERP in the business school curriculum." Association for Computing Machinery. Communications of the ACM, Apr 2000; 43:4, pp. 3941.

[2] Corbit, G. and J. Mensching. "Integrating SAP R/3 into a College of Business Curriculum: Lessons Learned," Information Technology and Management. 1:4, 2000, pp. 247-258.
Gill, G.T. and Q. Hu. "The Evolving Undergraduate Information Systems Education: A Survey of U.S. Institutions," Journal of Education for Business, 77:3, Jan.-Feb. 2002, pp. 151-158.

Hawking, P., B. McCarthy, and A. Stein. "Second Wave ERP Education." Journal of Information Systems Education, Fall 2004; 15:3, pp. 327-332.

[3] Hayen, R.L., M.C. Holmes, and J.J. Cappel. “A Framework for SAP R/3 Enterprise Software Instruction," Journal of Computer Information Systems. 40:2, 1999, pp. 79-85.

[4] Hayen, R. and Cappel, J.J. "Enterprise Software Certification Academy: A Longitudinal Study," The Journal of Computer Information Systems, 43:3, 2003. ABI/INFORM Global.

[5] Hayen, R.L., D.E. Vetter, and Z. Huang. "Using ERP in Curriculum Integration: A Case Study," Issues in Information Systems. 8:1, 2007, pp. 204210.

Joseph, G. and A. George. "ERP, learning communities, and curriculum integration." Journal of Information Systems Education, 2002; 13:1, pp. 5158.

[6] Laudon, K. C. and J. P. Laudon. Management Information Systems, $8^{\text {th }}$ ed., Prentice-Hall, Upper Saddle River, NJ, 2004.

Lee, J. "Business Process Courses in AACSBAccredited Graduate Programs of Business," Review of Business Research, 7:4, 2007, pp. 87-91.

Lee, J.S. "Status of business process courses inAACSB-Accredited undergraduate programs." The Journal of Computer Information Systems. Fall 2008; 49:1, pp. 10-16.

Lightfoot, J. "Fads versus Fundamentals: The Dilemna for Information Systems Curriculum Design." Journal of Education for Business. September/October 1999; pp. 43-49.

[7] MacKinnon, R. "Integration of ERP in the Business Curriculum." Issues in Information Systems, 2002; 3. ABI/INFORM Global.

Sager, J., J. Mensching, G. Corbitt, and J. Connolly. "Market Power of ERP Education - An Investigative Analysis." Journal of Information Systems Education, 2006, 17:2, pp. 151-161. 
Samuel, M., CYang, and YiZhang. "The Changing Information Systems (IS) Curriculum: A Survey of Undergraduate Programs in the United States," Journal of Education for Business, 81:6, July-August 2006, pp.291-299.

[8] "SAP Academy Certification." College of Business Administration SAP University Alliance Program, 2006.

http://sapua.cba.cmich.edu/default2.asp?33\%2E5

(November 2009)

[9] "SAP University Alliance Program - Americas." SAP Community Network, 2009. http://www.sdn.sap.com/irj/scn/index?rid=/library/uu id/a0edea1b-25ca-2b10-5da7-

fba8695ad884\&overridelayout=true. (November 2009)

[10] Stair, R. and G. Reynolds. Principles of Information Systems: A Managerial Approach, 8th ed., Thomson Course Technology, Boston, MA, 2008, pp. 343-374.

[11] "TERP10 - mySAP ERP - Integration of Business Processes Course Description." SAP America, 2009. http://www.sap.com/usa/services/education/catalog/g lobaltabbedcourse.epx? context=[[|TERP10||1|062|US| ]]|. (November 2009)

Trauth, E., D. Farwell, and D. Lee. "The IS Expectation Gap: Industry Expectations Versus Academic Preparation," MIS Quarterly, 17:3, 1993, pp. 293-307. 